Egyptian Poultry Science Journal

http://www.epsj.journals.ekb.eg/

ISSN: 1110-5623 (Print) - 2090-0570 (Online)

\title{
CORRELATED RESPONSE ON LITTER TRAITS AND MILK YIELD IN NEW ZELAND WHITE RABBITS SELECTED FOR LITTER SIZE AT BIRTH
}

\author{
Mahmoud M. El-Attrouny ${ }^{1}$ and Walid S. Habashy ${ }^{2}$
}

${ }^{1}$ Dep. of Anim. Prod., Fac. of Agric. at Moshtohor, Benha Uni., Egypt

${ }^{2}$ Dept. of Anim. and Poult. Prod, Fac. of Agric., Damanhour Uni., Egypt

Corresponding author:: Mahmoud M. El-Atrouny E-mail: Mahmoud.elatrouny@ @agr.bu.edu.eg

Received: 02/08/2020 Accepted: 26/08/2020

\begin{abstract}
The current study evaluated the influence of selection for litter size at birth on litter traits and milk yield of New Zealand White (NZW) rabbits. A total of 2231 litters produced from 360 does and 72 bucks were used to assess litter size at birth (LSB) and weaning (LSW), litter weight at birth (LWB), litter weight at $21 \mathrm{~d}$ (LW21) and litter weight at weaning (LWW), as well as mortality percentage (MOR\%) from birth (total alive) till weaning age, milk yield at lactation intervals of 0-7 d (MY07), 7$14 \mathrm{~d}$ (MY14), 14-21 d (MY21), 21-28 d (MY28) and 0-28 d (TMY) and milk conversion ratio during $21 \mathrm{~d}$ of lactation (MCR021). Multi-trait animal model was used to data analysis using VCE6 programe. Estimates of heritability for litter traits were low and ranging from 0.05 for LSB to 0.14 for LWB. Also, estimates for milk yield traits were low and ranged from 0.08 for MY7 to 0.22 for MY21. The contrast among these generations were significant $(\mathrm{P}<0.05)$, favoring the selected generations over the base population. Estimates of genetic correlations between litter traits were positively and ranged from low (0.06) between LSW and LWB to moderate $(0.51)$ between LWB and LW21. Genetic correlation between milk yield traits at different periods of lactation ranged from low (0.19) between MY7 and MY28 to high (0.84) between MY21 and TMY, while negative correlation between MY7 and TMY (-0.29). The accumulative correlated selection responses were positively and significant for litter traits and milk traits, while neagative and significant for MOR \%, positive and non significant for MCR\%. Conclusively, The selection of NZW does for litter size at birth could be efficient to improve litter traits and milk yield traits.
\end{abstract}

Keyword: correlated response, contrast, litter traits, milk yield, heritability, selection 
Mahmoud M. El-Attrouny ${ }^{1}$ and Walid S. Habashy ${ }^{2}$

\section{INTRODUCTION}

Rabbits used in many countries around the world as a source of white meat. According to FAOSTAT (2017), the largest-producer of rabbit meat in the world is China followed by Korea, Egypt, Spain and Italy. Moreover, several countries in Europe and some countries in North African countries consume rabbit meats (FAOSTAT, 2017) . In most of these nations, rabbit meats have a significant role in raising national economy.

Rabbit meats are recognized to be an excellent source of nutrients and have dietetic properties (Dalle Zotte, 2002; Combes, 2004; Hernàndez and Gondret, 2006). Rabbit meats are favorable mainly for reasons involving low fat and cholesterol $(3.4 \mathrm{~g} / 100 \mathrm{~g}$ meat), high protein (approxametly 22\%), high essential amino acid concentration and constant of mineral content $(1.3 \mathrm{~g} / 100 \mathrm{~g}$ meat $)$. Also, it provides moderately high energy (751 $\mathrm{KJ} / 100 \mathrm{~g}$ meat), a good source for vitamin B, low sodium level and rich in phosphorus. (Dalle Zotte, 2002 ; Dalle Zotte and Szendro, 2011) it can replace chicken in most of the cases. From the above, it is clear the importance of rabbits as a source of animal protein and national income, which requires further studies and development of programs for genetic improvement of rabbits.

It has been reported that there were three directions of selection to improve the productivity in rabbit. Basically, the first direction of selection is mainly used to improve profilicacy and lactation in maternal line. The second direction is genetic selection in paternal line to improve growth and carcass traits. The last one is selection in multi purpose lines to improve litter and growth traits together (Khalil and Al-Saef, 2008).
However, many authors reported that the most common direct parameter used in maternal lines selection programs was related to either litter size at birth or at weaning (El-Raffa, 2000; Al-Saef et al., 2008).

Litter size is one of the most economic important traits in rabbit production (Abou Khadiga, 2004 ; Belhadi, 2004 ; Nofal et al., 2005) which should be given concern in rabbit breeding programmes. Litter size is affected by many component traits such as ovulation, fertilization, embryo development, and fetal survival (Argente, 2016).

Milk production of doe rabbit can be strongly affected by number of sulking kits and kits weight at birth (ElMaghawry et al., 1993 ; Pascual et al., 1996). Many studies stated that milk production of rabbit doe can be increased with heavier litter weight at birth, due to the increase of uterine induction or suclking kits number (Bolet et al., 1996 and Petersen et al., 1996). Does' milk production plays a major factor affecting on litter weight and pre weaning litter growth (Khalil et al., 2004). Milk production could be limited by additive gene effects and positively correlated with litter weight at birth (Ayyat et al., 1995; Lukefahr et al., 1996)

Improving the productivity of the rabbits depends on the estimation of genetic parameters (e.g; heritability, genetic and phenotypic correlations) for economic traits (Khalil et al., 1987). Hence, this study aimed to investigate the selection effect for litter size at birth on litter traits and milk yield traits, to estimate genetic parameters, to estimate selection correlated responses for unselected traits. 
correlated response, contrast, litter traits, milk yield, heritability, selection

\section{MATERIALS AND METHODS Animals, Population structure and housing and feeding}

The current study was carried out at the commercial Rabbitry Farm in Qalyubia Governorate, Egypt, during the period from January 2019 to March 2020 on New Zealand White (NZW) rabbits. New Zealand White maternal rabbit selected during two generations for litter size at birth. Data from 2231 litters produced from 360 does and 72 bucks (base population and two selected generations), fathered by 102 sires and mothered by 288 dams were used in this experiment. Growing rabbits were weaned at four weeks of age and were raised in a semiclosed rabbitry. Breeding sires and does were housed individually in a separate wire cages $\left(50 \times 50 \times 30 \mathrm{~cm}^{3}\right)-$ All animals, in the rabbitry, were kept under controlled environmental conditions with temperature ranged from $22{ }^{\circ} \mathrm{C}$ to $30{ }^{\circ} \mathrm{C}$, relative humidity from $24 \%$ to $50 \%$ and lighting program of $16 \mathrm{hr}$ light and $8 \mathrm{hr}$ dark. Each buck was mated to 5 does. Actually, the average age of rabbits used at the first mating was around 4.5-5 months-old and, after delivering, the new mating was tried 10 days later. Does were mated in the bucks' cage and logged individually. Sire-daughter, full and half sib matings were avoided. Each doe was palpated after 10 days for pregnancy detection. Those does failed to conceive were returned to the same mating-buck at the day of test. Metal nest boxe was provided for each doe at 26 days from conceiving fertile mating .

Growing rabbits were fed a commercial pelleted diet, containing $17.9 \%$ crude protein, $15.52 \%$ crude fiber, $2.45 \%$ ether extract, 58.5 nitrogen free extract, and $6.29 \%$ ash, while breeding rabbits were provided with a pelleted rabbit diet containing $17.4 \%$ crude protein, $13 \%$ crude fiber and $2.54 \%$ fat on dry matter basis, according to NRC (1977), during the whole experimental period. Feed and drinking water were provided ad libitum. All growing and breeding rabbits were kept under the same managerial, hygienic and environmential contions.

\section{Data collection}

Milk yield (MY) of does was recorded during the first seven days (MY7), 7-14 days (MY14), 14-21 days (MY21), 21-28 days (MY28) and 0-28 days (TMY) using weigh-suckle-weigh method described by Lukefahr et al. (1983) and Khalil (1994). Briefly, the kits were separated from their dams in the evening to prevent suckling for a period of $12 \mathrm{~h}$, weighed in the morning and then placed in the nest box of the doe's cage. Afterthat, each doe entered the box, nursed the litter and left within 3 to $5 \mathrm{~min}$. The litters and the dam were reweighed separately and returned to the nest box and cage, respectively. For avoiding any biased estimates of MY (e.g., in case the kits or the does urinated), the MY of each doe was estimated by the average difference between the pre- and post-suckling weight of both the litter and doe. Data collected were litter size at birth (LSB, kids) and weaning (LSW, kids), litter weight at birth (LWB, g), litter weight at $21 \mathrm{~d}$ (LW21, g) ; and litter weight at weaning (LWW, g), mortality percentage $\%$, milk yield at lactation intervals of 0 7d (MY7, g), 7-14 d (MY14, g), 14-21 d (MY21,g), 21-28(MY28) and 028(TMY028), milk conversion ratio as $\mathrm{g}$ of litter gain per $\mathrm{g}$ of milk suckled during $21 \mathrm{~d}$ of lactation (MCR021, g/g).

\section{Statistical analysis}

Data of litter and milk traits were analysed using the multi-trait animal model as follows: 
Mahmoud M. El-Attrouny ${ }^{1}$ and Walid S. Habashy ${ }^{2}$

$\mathrm{y}=\mathrm{Xb}+\mathrm{Z}_{\mathrm{a}} \mathrm{u}_{\mathrm{a}}+\mathrm{e}$

Where $\mathrm{y}=$ The vector of observations; $\mathrm{b}$ $=$ The vector of fixed effects of generation (two levels); $\mathrm{X}$ and $\mathrm{Za}=$ Incidence matrices corresponding to fixed and additive random effects of the dam $\left(u_{a}\right)$, respectively; $\mathrm{e}=$ Vector of random residual effects. The VCE6 software was used to estimate the variance components of random effects and heritabilities (Groeneveld et al., 2010). These estimates were used to solve the corresponding mixed model equations, obtaining solutions for the generation effects and their error variance covariance matrix using the PEST software (Groeneveld, 2006). Estimates of the contrasts between the three generations of selection were obtained by the least-squares analysis using the VCE6 software. The correlated selection response (CSR) at generation (n) was calculated by the following equation of Falconer and Mackay (1996):

$\mathrm{CSRy}=\mathrm{i}_{\mathrm{X}} \mathrm{h}_{\mathrm{x}} \mathrm{h}_{\mathrm{y}} \mathrm{r}_{\mathrm{g}} \sigma_{\mathrm{py}}$

Where: CSRy = The correlated selection response in trait $\mathrm{y}, \mathrm{i}=$ The selection intensity for trait $\mathrm{x}, \mathrm{hx}$ and hy $=$ Square roots of heritability for traits $\mathrm{x}$ and $\mathrm{y}$, respectively, $r_{g}=$ The genetic correlation of traits $\mathrm{x}$ and $\mathrm{y}$, and $\sigma_{\mathrm{py}}=$ The phenotypic standard deviation of trait $y$.

\section{RESULTS AND DISCUSSION} Actual means and Coefficient of variability

Actual means, standard deviations (SD) and and coefficients of variation (CV\%) for litter and milk yield traits are presented in Table 1. Averages of LSB, LSW,LWB, LW21 and LWW were 7.87 kids, 6.96 kids, $518 \mathrm{~g}, 1825 \mathrm{~g}$ and $3132 \mathrm{~g}$, respectively. These results higher than those reported by many researchers (Iraqi , 2008 ; Okoro et al., 2012; EL-Deghadi, 2019; Rabie et al., 2019) . In contrast, results in these study were lower than previous study observed by Costa et al. (2004) and Ziadi et al., (2013). Mean of LW21was $1825 \mathrm{~g}$ which is similar to that findings by Iraqi (2008), while lower than those reported by EL-Deghadi (2019) in NZW rabbits. Al-Saef et al., (2008) stated that the actual means for LSB, LSW, LWB, LW21 and LWW were 9.26 young, 7.69 young, 438g, $1748 \mathrm{~g}$ and $3370 \mathrm{~g}$, respectively in rabbits.

Coefficients of variability (CV \%) ranged from 12.0 to $23.8 \%$ for litter traits. These trends are similar to that findings by (El-Maghawry, 1999; Youssef et al.,2008 and Iraqi, 2008 and Okoro et al., 2012). These results confirm the hypothesis that the selection for litter size increase the number of total born these traits.In addition, these results may indicate higher reproductive performance of doe.

Means of mortality percentage from 1 to 28 days was $13.25 \%$ slightly higher than showed by Johnson et al. (1988). This mortality may be likely to poor nursing ability of doe, lack of suckling drive by the kits, non specific enteritis and increase of litter size (Rashwan and Marai,2000).

In the present study, actual means for MY7, MY14, MY21, MY28 days and TMY were 670, 979,1214, 939 and 3779 g, respectively. Similar results showed by (Youssef et al., 2008 ; Abou Khadiga et al., 2012 ;El-Deghadi,2019). The same trend showed by Iraqi and Youssef (2006) who reported that the means for MY1, MY2, MY3, MY4 wks and TMY were 644.1, 963.8, 1136.7, 877.0 and $3538 \mathrm{~g}$, respectively in NZW rabbits.

Coefficients of variability (CV \%) ranged from 25.19 to $37.56 \%$ for milk production traits. This verifies that these traits in rabbits are influenced by various 
correlated response, contrast, litter traits, milk yield, heritability, selection

effects such as genetic make up of the does, non-genetic effects. These results agree with the findings of El-Maghawry (1999) , Ramadan (2005) and Iraqi (2008) . El-Deghadi (2019) reported that coefficients of variability for milk yield through the intervals of lactation were modeate and varied from $36.09 \%$ to $66.39 \%$

\section{Contrasts between selected generations and base population}

Table 2 shows the contrasts employed between selected generations and base population for litter and milk traits, was superior to selected generations for LSB, LSW, LWB, LW21 and LWW when comparision with base population (differences of 1.62 young, 1.56 young, $84 \mathrm{~g}, 143 \mathrm{~g}$ and $452 \mathrm{~g}$, respectively $(\alpha=$ $0.05)$. Similar results were reported by García and Baselga, (2002); Ragab and Baselga, (2011). Estimates of contrast between selected generations and base population for milk traits are given in Table 2. The contrast among estimates of these generations was significant $(\mathrm{P} \leq 0.05)$ for MY7 (145g), MY14 (117g), MY21 (197g), MY28 (96g) and TMY $(555 \mathrm{~g})$, favoring the selected generations.

\section{Heritability estimates}

In the present study, estimates of heritability $\left(\mathrm{h}^{2}\right)$ for LSB, LSW, LWB, LW21 and LWW are low and ranging from 0.05 to 0.14 (Table 2). These estimates were within the range of the literature estimates (ranged from 0.0 to 0.17 ) for litter traits reported by (Ferraz and Eler, 1996; Sorensen et al., 2001, Iraqi , 2008; Al-Saef et al., 2008; Iraqi et al., 2010). Similarly, low estimates of $\mathrm{h}^{2}$ for litter size and weight traits ranging from 0.0 to 0.13 were repoted by Johnson et al. (1988), Baselga et al. (1992), Khalil, (1994), Lukefahr and Hamilton, (1997), Baselga and Garcia,
(2002) and Nofal et al. (2002). Iraqi et al. (2010) reported that $\mathrm{h}^{2}$ estimate for LSB and LSW was 0.06 and 0.07 in rabbits. Iraqi et al. (2006) found that estimates of $h^{2}$ was low and values were $0.04,0.01,0.08$, and 0.09 for LSB, LWB, LSW and LWW, respectively. Ayyat et al. (1995) found that estimates of $\mathrm{h}^{2}$ for litter size traits ranging from 0.09 (LSW) to 0.22 (LSB) in NZW rabbits. However, Fayeye and Ayorinde, (2016) found that heritability for LSB, LWB, LSW and LWW were 0.60, 0.96, 0.84 and 0.92 , respectively In this stdudy, hertability for MOR ratio was (0.04 \%). Johnson et al. (1988) found that percent mortality from 1 to 28 days was 0.08 in NZW rabbits. Low and moderate heritability estimates for these traits may likely due to lower additive gene effect for these traits

In the current study estimates of heritability $\left(\mathrm{h}^{2}\right)$ for MY7, MY14, MY21, MY28 and TMY traits were $0.08, \quad 0.19, \quad 0.22, \quad 0.17$ and 0.21 , respectively (Table 2). Some authors have reported estimates similar to ours ( El-Maghawry et al., 1993 ; Ayyat et al., 1995; Al-Saef et al., 2008 ; El-Deghadi, 2019).

Iraqi and Youssef (2006) reported that estimates of $h^{2}$ for milk production traits were low and ranged from 0.001 for total milk yield during $4^{\text {th }}$ wks to 0.05 for total milk yield during $3^{\text {rd }}$ wk. Iraqi (2008) reported that estimates of $h^{2}$ for milk production traits ranged from 0.0 to 0.11 for milk yield traits in NZW rabbits. Youssef et al.(2008) reported that $\mathrm{h}^{2}$ estimates for milk production traits in NZW and Baladi Black rabbits were low and ranged from 0.01 to 0.12 . Al-Sobayil et al. (2005) reported that $\mathrm{h}^{2}$ for MY traits were moderate, ranging from 0.18 to 0.22 in rabbits. Gómez -Ramos et al. 
Mahmoud M. El-Attrouny ${ }^{1}$ and Walid S. Habashy ${ }^{2}$

(2010) showed that the $\mathrm{h}^{2}$ of milk yield was low (0.12). Khalil et al. (1986) and Ayyat et al. (1995) mentioned that maternal and environmental effects are the main variation sources and the cause of low estimates of $h^{2}$ estimates for MY in rabbits. Differences between $h^{2}$ estimates might also be due the type of breed, environmental conditions, management and statistical methods used. In the present study, heritability estimates for MCR021 was low (0.09). these results agree with the findigs of Iraqi (2008), Al-Saef et al. (2008) and El-Deghadi (2019).

Genetic and phenotypic correlations

Estimates of genetic $\left(\mathrm{r}_{\mathrm{G}}\right)$, correlations between litter size traits are given in Table 3. Estimates of $r_{G}$ were positively and very different (ranged from 0.06 to 0.51 ). Litter size at birth had moderate genetic correlation (0.41) with litter weight at 21 day. This result indicates that selection for litter size at birth will increase LW21. This finding agree with the findings of Odubote and Somade (1992) and Sorensen et al. (2001). Hassan et al. (2015) found that all estimates of genetic correlations between LWB and LWW were high and positive. Based on the results of the present study, we can suggest that selection for LSB would be effective to improve other litter traits. On the other hand, phenotypic correlations among litter traits were positive and ranged from low $(0.11)$ to moderate (0.31) (Table 3).

In the current study, genetic correlation between milk yield traits at different periods of lactation ranged from moderate (0.19) between MY7 and MY28 day to high (0.86) between MY21 and TMY. This indicates that milk production during the $3^{\text {rd }}$ wk of lactation is closely correlated with TMY. Thus, one would recommend the rabbit breeders to select the does according to milk yield of the third week of lactation to obtain genetic progress of total milk production in NZW does. This agrees with the findings by Iraqi and Youssef (2006).

Hassan (2005) showed that milk production traits in NZW rabbits were mostly genetically correlated. On the other hand, moderate and negative genetic correlation (-0.29) between milk yield during the first and fourth weeks of lactation was obtained in the present study. This indicates that as milk production increased during the first week (because increasing the activity of mammary gland gradually), the milk lactation decreased during the $4^{\text {th }}$ wk because of the inhibition of the prolactin hormone by oestrogens and progesterone which due to that most of the does were in the late periods of pregnancy at that time (Lebas, et al. 1997) and the increase of dry ration consumed by the young simultaneously. In general, the similar trend for phenotypic correlations between milk production traits was obtained (Table 4).

\section{A ccumulative selection responses}

A ccumulative selection response after two selected generations was favorable for all unselected litter traits and showed the superiority of the selected generations compared to the base population (Table 5). Responses were significant $(\mathrm{P}<0.05)$ for LSW(1.34 kids), LWB (70.6 g), LW21 (113 g) and LWW (314 g), while was significant and negative for MOR ($1.21 \%)$ after two selected generations. This demonstrated that, selection for LSB was correlated with an increase other litter traits. Blasco et al., 1993 reported that direct selection for litter size in pigs and rabbit did not observe an expected success. García and Baselga (2002) 
correlated response, contrast, litter traits, milk yield, heritability, selection

reported that approximately 0.1 young per generation in rabbits has been identified as selection response for litter size. On the other hand, accumulative selection response for milk yield traits was superiority of selected generation Table 5 . Responses were significant $(\mathrm{P}<0.05)$ for MY7 (137g), MY14 (124 g), MY21 (189 $\mathrm{g})$, MY28 (102 g) and TMY (537 g). This reflects, the selection for LSB in NZW rabbits through two selection generations increased with advanced generations.

\section{CONCLUSION}

Although estimates of heritability for traits of LSB, LSW, LWB, LW21 and LWW were low, these are the highest estimates of heritability compared to the other traits under the current study.
Therefore, the selection of NZW does rabbits could be effective for improving these traits. Also, estimate of heritability for milk yield in the $3^{\text {rd }}$ wk of lactation was the highest compared with the other traits. Consequently, it is recommended that selection of NZW does rabbits at that week could be effective to improve TMY in NZW rabbits.

Superiorities in the selected generations indicated that selection for LSB in NZW rabbits was associated with an improvement in other litter traits and milk yield traits .In addition, the cumulative correlated responses of selection for LSB in rabbits through two selection generations increased with generations.

Table (1): Descriptive statistics for litter size and milk traits (mean, standard deviation (SD), coeffient of variation (CV\%) and extreme values).

\begin{tabular}{|l|c|c|c|c|c|c|}
\hline Traits & No. & Mean & SD & CV & Minimum & Maximum \\
\hline \multicolumn{7}{|l|}{ Litter traits } \\
\hline LSB (kids) & 3214 & 7.87 & 1.87 & 23.8 & 2 & 13 \\
LSW (kids) & 3109 & 6.96 & 1.11 & 16.0 & 1 & 9 \\
LWB (g) & 3214 & 518 & 100.0 & 19.30 & 134 & 859 \\
LW21 (g) & 3136 & 1825 & 242.0 & 13.26 & 541 & 3214 \\
LWW (g) & 3088 & 3132 & 371.0 & 12.0 & 541 & 5241 \\
MOR (\%) & 387 & 13.25 & 3.63 & 27.31 & 1 & 5 \\
\hline Milk traits & \multicolumn{7}{|l}{} \\
\hline MY7 (g) & 448 & 670 & 200 & 29.85 & 350 & 953 \\
MY14(g) & 448 & 979 & 312 & 31.86 & 589 & 1352 \\
MY21(g) & 447 & 1214 & 456 & 37.56 & 652 & 1758 \\
MY28(g) & 446 & 939 & 321 & 34.18 & 349 & 1365 \\
TMY(g) & 443 & 3779 & 952 & 25.19 & 2752 & 5635 \\
MCR021 (g/g) & 447 & 0.46 & 0.23 & 49.21 & 0.17 & 0.67 \\
\hline
\end{tabular}

${ }^{a}$ LSB = Litter size at birth; LSW = Litter size at weaning; LWB = litter weight at birth; LW21 = Litter weight at $21 \mathrm{~d} ; \mathrm{LWW}=$ Litter weight at weaning age; Mortality $\%$ of kids [from birth (total alive till weaning)

${ }^{\mathrm{b}}$ MY7 = Milk yield at lactation intervals of 0-7 d (MY7); 7-14d (MY14); 14-21D (MY21) ;21 28 (MY28) and 0-28 (TMY). MCR021 = Milk conversion ratio as $\mathrm{g}$ of litter gain per $\mathrm{g}$ of milk suckled during $21 \mathrm{~d}$ of lactation. 
Mahmoud M. El-Attrouny ${ }^{1}$ and Walid S. Habashy ${ }^{2}$

Table (2): Contrast ( \pm Standard errors) between selected and base population, and heritabilities and their standard errors $\left(\mathrm{h}^{2} \pm \mathrm{se}\right)$ for the studied traits.

\begin{tabular}{|l|c|c|}
\hline Traits & $\begin{array}{c}\text { Contrast } \\
\text { Selected vs. Base }\end{array}$ & $\mathbf{h}^{2} \pm \mathbf{s e}$ \\
\hline Litter traits $^{\mathbf{a}}$ & & 0.05 \\
\hline LSB (kids) & $1.62^{*}$ & 0.07 \\
LSW (kids) & $1.56^{*}$ & 0.14 \\
LWB (g) & $84^{*}$ & 0.09 \\
LW21(g) & $143^{*}$ & 0.06 \\
LWW (g) & $452^{*}$ & 0.04 \\
MOR (\%) & -1.42 & \\
\hline Milk traits & & 0.08 \\
\hline MY7 (g) & $145^{*}$ & 0.19 \\
MY14(g) & $117^{*}$ & 0.22 \\
MY21(g) & $197^{*}$ & 0.17 \\
MY28(g) & $96^{*}$ & 0.21 \\
TMY(g) & $555^{*}$ & 0.09 \\
MCR021 (g/g) & 0.04 & \\
\hline
\end{tabular}

*Significance of the contrast at $\mathrm{P} \leq 0.05$

Table (3): Estimates of genetic (above the diagonal) and phenotypic correlations (below the diagonal) and standard errors (in parenthesis) between the litter traits of NZW rabbits.

\begin{tabular}{|c|c|c|c|c|c|c|}
\hline $\begin{array}{l}\text { Traits } \\
\text { correlated }\end{array}$ & LSB & LSW & LWB & LW21 & LWW & MOR \\
\hline LSB & - & $0.32(0.14)$ & $0.38(0.15)$ & $0.41(0.16)$ & $0.18(0.12)$ & $0.13(0.06)$ \\
LSW & $0.14(0.07)$ & - & $0.06(0.07)$ & $0.32(0.14)$ & $0.37(0.17)$ & $-0.21(0.10)$ \\
LWB & $0.23(0.08)$ & $0.11(0.08)$ & - & $0.51(0.22)$ & $0.27(0.12)$ & $0.15(0.09)$ \\
LW21 & $0.18(0.02)$ & $0.14(0.07)$ & $0.25(0.15)$ & - & $0.39(0.15)$ & $0.16(0.11)$ \\
LWW & $0.15(0.07)$ & $0.21(0.11)$ & $0.31(0.16)$ & $0.23(0.09)$ & - & $0.17(0.05)$ \\
MOR & $0.16(0.07)$ & $-0.16(0.12)$ & $0.13(0.07)$ & $0.19(0.11)$ & $0.22(0.11)$ & - \\
\hline
\end{tabular}


Table (4): Estimates genetic (above the diagonal) and phenotypic correlation (below the diagonal) correlations and standard errors (in parenthesis) between traits of milk yield of NZW rabbits.

\begin{tabular}{|c|c|c|c|c|c|c|}
\hline $\begin{array}{l}\text { Traits } \\
\text { correlated }\end{array}$ & MY7 & MY14 & MY21 & MY28 & TMY & MCR021 \\
\hline MY7 & - & $0.31(0.12)$ & $0.34(0.14)$ & $0.19(0.16)$ & $0.41(0.19)$ & $0.21(0.11)$ \\
MY14 & $0.24(0.11)$ & - & $0.47(0.17)$ & $0.21(0.14)$ & $0.63(0.21)$ & $0.24(0.11)$ \\
MY21 & $0.23(0.11)$ & $0.32(0.18)$ & - & $0.28(0.17)$ & $0.86(0.22)$ & $0.22(0.13)$ \\
MY28 & $0.27(0.13)$ & $0.19(0.12)$ & $0.27(0.14)$ & - & $0.48(0.15)$ & $0.21(0.10)$ \\
TMY & $0.41(0.17)$ & $0.54(0.18)$ & $0.76(0.18)$ & $0.39(0.16)$ & - & $0.20(0.11)$ \\
MCR021 & $0.12(0.08)$ & $0.14(0.07)$ & $0.10(0.05)$ & $0.11(0.05)$ & $0.13(0.02)$ & - \\
\hline
\end{tabular}

Table (5): Estimates of cumulative selection response (CSR) and their ( \pm standard errors) for the unselected traits through two generations of selection.

\begin{tabular}{|c|c|}
\hline Traits & CSR \\
\hline \multicolumn{2}{|l|}{ Litter traits } \\
\hline LSW & $1.34 \pm 0.34^{*}$ \\
\hline LWB (g) & $70.6 \pm 16.5^{*}$ \\
\hline LW21 (g) & $113 \pm 10.3^{*}$ \\
\hline LWW (g) & $314 \pm 34.2^{*}$ \\
\hline MOR $(\%)$ & $-1.21 \pm 0.07^{*}$ \\
\hline \multicolumn{2}{|l|}{ Milk traits } \\
\hline MY7(g) & $137 \pm 18.6^{*}$ \\
\hline MY14 (g) & $124 \pm 24.5^{*}$ \\
\hline MY21 (g) & $189 \pm 31.2^{*}$ \\
\hline MY28 (g) & $102 \pm 20.2^{*}$ \\
\hline TMY0-28 (g) & $537 \pm 47.2^{*}$ \\
\hline MCR021 (g/g) & $0.03 \pm 0.002$ \\
\hline
\end{tabular}

${ }^{*}$ Significance at $\mathrm{P} \leq 0.05$ 
Mahmoud M. El-Attrouny ${ }^{1}$ and Walid S. Habashy ${ }^{2}$

\section{REFERENCES}

Abou Khadiga, G. 2004. Performance of the Spanish synthetic line (V) and the local Baladi Black Rabbits and their crosses under Egyptian conditions. M. Sc. Thesis. Faculty Agriculture, Tanta University, Kafr ElSheikh, Egypt.

Abou Khadiga, G., Youssef, Y. M. K. and Baselga, $M .2012$. Characterization of reproductive performance of the APRI line of rabbits. Proceedings $10^{\text {th }}$ World Rabbit Congress, Sharm El- Sheikh -Egypt, 743- 747.

Al-Saef, A.M., Khalil, M.H., AlHomidan, A. H., Al-Dobaib, S.N., Al Sobayil, K.A., Garcia, M.L. and Baselga, M. 2008. Crossbreeding effects for litter and lactation traits in a Saudi project to develop new lines of rabbits suitable for hot climates. Livestock Science, 118:238-246.

Al-Sobayil, K.A., Al-Homidan, A.H., Khalil, M. H. and Mehaia, M.A. 2005. Heritabilities and genetic analysis of milk yield and components in crossing project of Saudi rab-bits with Spanish V-line. Livestock Research.for Rural Developoment, 17:117.

Argente, M. J. 2016. Major Components in Limiting Litter Size, Insights from Animal Reproduction, Rita Payan Carreira, IntechOpen.

Ayyat, M. S., Marai, I. F. M. and ElSayaid, G. H. A. 1995. Genetic and non-genetic factors affecting milk production and pre-weaning litter traits of New Zealand White does under Egyptian conditions.World Rabbit Science, 3:119-124.

Baselga, M. and García, M. L. 2002. October. Evaluating the response to selection in meat rabbit programmes.
In Proc. 3rd Scientific Conference of Rabbit Production in Hot Climates, 2002 October, Hurghada, Egypt, 1 (Vol. 10).

Baselga, M., Gomez, E., Cifre, P. and Camacho, J. 1992. Genetic diversity of litter size traits between parities in rabbits. In: Proceedings $5^{\text {th }}$ World Rabbit Congress, Oregon State University, Corvallis, USA, July, A, 198-205.

Belhadi, S. 2004. Characterization of local rabbit performances in Algeria: Environmental variation of litter size and weights. In: Proceedings $8^{\text {th }}$ World Rabbit Congress, Puebla, Mexico. A., 218-223.

Blasco, A., Bidanel J. P., Bolet, G., Haley, C. and Santacreu, M. A. 1993. The genetics of prenatal survival of pigs and rabbits: a review. Livestock Prod. Sci. 37:1-21.

Bolet, G., Esparbie, J. and Falieres, J. 1996. Relations entre nombre de foetus par corne uterine, la taille de portee a la naissance et la croissance ponderale des lapereaux. Annales de Zootecchnie, 45:186-200.

Combes, S. 2004. Valeur nutritionnelle de la viande de lapin. INRA Production Animales, 17, 373-383.

Costa, C., Baselga, M., Lobera, J., Cervera, C. and Pascual, J. J. 2004. Evaluating response to selection and nutritional needs in a three way cross in rabbits. Journal of Animal Breeding and Genetics, 121: 186-196.

Dalle Zotte, A. and Szendrö, Z. 2011. The role of rabbit meat as functional food. Meat Science, 88:319-331.

Dalle Zotte, A. 2002. Perception of rabbit meat quality and major factors influencing the rabbit carcass and meat 
correlated response, contrast, litter traits, milk yield, heritability, selection

quality. Livestock Production Science, $75: 11-32$

El-Deghadi, A. S. 2019. Factors affecting milk production and using application selection indices to improve productive traits of does in New Zealand White rabbits. Egyptian Journal of Rabbit Science, 29 : 61-78.

El-Maghawry , A. M. 1999. Genetic effects on some doe productivity in New Zealand White and Californian raised in Egypt. Egyptian Journal of Rabbit Science, 9: 179-195.

El-Maghawry, A. M., Soliman, A. M. and Khalil, H. H. 1993. Doe milk production as affected by some genetic and environmental factors in New Zealand White and Californian rabbits under the Egyptian conditions. Egyptian Journal of Rabbit Science, 3: 141-150.

El-Raffa, A.M. 2000. Animal model evaluation of $\mathrm{V}$ Line Rabbits raised under Egyptian conditions. Egyption Poultry Science, 20: 1003-1016

Falconer, D. S. and Mackay, F. C. 1996. Introduction to Quantative Genetics."4th Edition "Longman Group Ltd, England.

FAOSTAT, 2017. Available at: http://faostat.fao.org/site/291/default.a spx

Fayeye, T. R. and Ayorinde, K. L. 2016. Heritability and repeatability estimates for birth and weaning characteristics in domestic rabbit. International Journal of Agricultural and Veterinary Sciences, 2: 11.

Ferraz, J. B. S. and Eler, J. P. 1996. Comparison of animal models for estimation of (co) variance components and genetic parameters of reproductive, growth and slaughter traits of Californian and New Zealand White rabbits raised under tropical conditions. $6^{\text {th }}$ World Rabbit Congress, Toulouse, France, 2:279-248.

García, M. L. and Baselga M. 2002. Estimation of genetic response to selection in litter size of rabbits using a cryopreserved control population. Livestock Production Science, 74: 4553.

Gómez-Ramos, B., Herrera-Camacho J., Ortiz-Rodríguez R., Candelario J., Carlos S.and Becerril-Pére $M$. 2010. Heritability ofmilk yieldin a population ofrabbits under the conditions of the valley of mexico[heredabilidad de la produccion de leche en unapoblacion de conejasbajocondiciones de el valle de mexico.tropical and subtropical Agroecosystems, 12,681-683.

Groeneveld, E. 2006. PEST User's Manual. Inst. Farm Animal Gen., Neustadt, Germany.

Groeneveld, E, Kovač M. and Mielenz N.2010. VCE User's Guide and Reference Manual, version 6.0. Institute of Farm Animal Genetics; Neustadt, Germany.

Hassan, N.S. 2005. Animal model evaluation and some genetic parameters of milk production in New Zealand White and Baladi Black Rabbits using DF-REML procedure. $4^{\text {th }}$ International Conference on Rabbit Production In Hot Climates, SharmElSheikh, Egypt, 55-64.

Hassan, N.S., Abdel-Ghany, A. M. and Sabri, H. M. 2015. Genetic Parameters of the Newly-Developed Egyptian APRI Rabbit Line Raised Under North-Delta Environment Using DF-REML Animal Model 1 Litter Weight Traits.E C Veterinary Science, 1:30-46.

Hernàndez, P. and Gondret, F. 2006. Rabbit meat quality. In L. Maertens, \& 
Mahmoud M. El-Attrouny ${ }^{1}$ and Walid S. Habashy ${ }^{2}$

P. Coudert (Eds.), Recent advances in rabbit sciences (pp. 269-290). Melle, Belgium: ILVO.

Iraqi, M. M. 2008. Estimation of heritability and repeatability for maternal and milk production traits in New Zealand white rabbits raised in hot climate conditions. Livestock Research for Rural Development 20 (8).

Iraqi, M. M. and Youssef, Y. M. K. 2006. Genetic analysis for milk production traits in New Zealand White rabbits raised in Egypt. Egyptian Journal of Rabbit Science, 16: 1-13.

Iraqi, M. M., Garcı́ a, M.L., Khalil, M. H. and Baselga M. 2010. Evaluation of milk yield and some related maternal traits in acrossbreeding project of Egyptian Gabali breed with SpanishV-line in rabbits. Journal of Animal Breeding and Genetics, 127: 242248.

Iraqi, M. M., Ibrahim, M. K., Hassan, N.S.H. and El-Deghadi, A. S. 2006. Evaluation of litter traitsin purebred and crossbred rabbits raised under Egyptian conditions. Livestock Research for Rural Development, 18, 83.

Johnson, Z. B., Harris, D. J., Brown, C. J., Getz, W. R. and Harrold, R. L. 1988. Genetic Analysis of Litter Size, Mortality and Growth Traits of New Zealand White Rabbits1. The Professional Animal Scientist, 4:1116.

Khalil, M. H. 1994. Lactational performance of Giza White rabbits and its relation with per-weaning litter traits. Animal Production 59: 141-145.

Khalil, M. H., Mehaia, M.A., AlHomidan, A.H. , Al-Sobayil, K.A. 2004. Genetic analysis for milk yield and components and milk conversion ratio in crossing of Saudi rabbits with V-line. The $8^{\text {th }}$ World Rabbit Congress. Puebla, Mexico.

Khalil, M. H., Owen, J. B. and Afifi, E. A. 1987. A genetic analysis of litter traits in Bauscat and Giza White rabbits. Anim. Prod, 45: 123-134

Khalil, M. H., Owen, J. B. and Afifi E.A. 1986. A review of phenotypic and genetic parameters associated with meat production traits in rabbits. Animal Breeding Abstracts, 54:725749.

Khalil, M.H. and Al-Saef, A.M. 2008. Methods, criteria, techniques and genetic responses for rabbit selection: a review. $9^{\text {th }}$ World Rabbit Congress Verona - Italy

Lebas, F., Coudert, P., Rochambeau, H. de. and Thebaut, R.G. 1997. The Rabbit Husbandry, health and production. page 54. Food and Agriculture Organization of the United Nation, Rome, 1997.

Lukefahr, S. D. and Hamilton, H. H. 1997. Heritability and repeatability estimates of maternal performance traits in purebred and crossbred does. World Rabbit Science, 5:99-105.

Lukefahr, S. D., Cheek, P. R. and Patton, N. M. 1996. Heritability of milk production and 21-day litter weight and litter size in purebred and crossbred rabbits using an animal model. In: proc. 6th World Rabbit Congr, Toulouse, France, 2: 319-323.

Lukefahr, S., Hohenboken, W. D., Cheeke, P. R. and Patton, N. M. 1983. Characterization of straight bred and cross-bred rabbits for milk production and associative traits. Jouranl of Animal Science. 57: 11001107. 
correlated response, contrast, litter traits, milk yield, heritability, selection

Nofal, R. Y., Abdel-Ghany, A. M., Saleh, K. 2002. Best linear unbiased prediction (BLUP) on some litter traits and Muscularity rate of New Zealand White rabbits under Egyptian conditions. $3^{\text {rd }}$ Science Congress On Rabbit Production in hot climates, 127-137.

NRC (1977). National Research Council. Nutrient Requirements of Domestic Animal. Nutrient Requirements of Rabbits. Washington, U.S.A.

Nofal, R., Saleh, K., Younis, H. and Abou Khadiga, G. 2005. Evaluation of Spanish synthetic line V, Baladi Black rabbits and their crosses under Egyptian conditions. 1. Litter size. In: Proceedings $\quad 4^{\text {th }} \quad$ International Conference Rabbit Production Hot Climates. Sharm El-Sheikh, Egypt. 2329.

Odubote, K. and Somade, B. 1992. Genetic analysis of rabbit litter traits at birth and weaning. Nigerian Jouranl of Animal. Production. 19: 64.

Okoro, V. M. O., Ogundu, U. E., Ukoli, I. C., Anyanwu, G. A., Chikaire, J., Raji, A. O. and Maduka, C. G. 2012. Estimation of heritability and repeatability for preweaning and post-weaning litter weight of unselected Domestic Rabbits in South EasternNigeria. International Journal of Agriculture and Forestry, 2: 7 - 10.

Pascual, J..J., Cervera, C., Blas, E. and Fernandez-Carmona, J. 1996. Milk yield and composition in rabbit does using high fat diets. 6th World rabbit Congress, Toulouse, France, Volume 1:259-262.

Petersen, J., Hartmann, J. and Mennicken, L. 1996. Effects of prenatal on postnatal performance of does. 6th World rabbit Congress, Toulouse, France, 2:103-106.

Rabie, T.S.K., Nowier, A.M., AbouZeid, A.E. and Khattab, A.S. 2019. Impact of crossing between Gabali and $\mathrm{V}$-line rabbits on the pre-weaning traits by using tri diagonal and genetic merit methods. Egyption Poultry Science, 39:519- 536.

Ragab, M. and Baselga, M. 2011. A comparison of reproductive traits of four maternal lines of rabbits selected for litter size at weaning and founded on different criteria. Livestock Production Science, 136, 201-206.

Ramadan, S. I. A. 2005. A study on the performance of rabbit doe for some litters, reproduction and milk production traits. M. Sc. Thesis, Faculty of Veterinary Med., Moshtohor Zagazig University, Benha Branch, Egypt.

Rashwan, A.A. and Marai, I. F. M. 2000. Mortality in young rabbits: a review. World Rabbit Science: 8:111124.

Sorensen, P., Kjaer, J. B., Brenoe, U.T. and Su, G. 2001. Estimation of genetic parameters in Danish White rabbits using an animal model: II. Littertraits. World Rabbit Sci. 91:3338.

Youssef , Y. M. K., Omara, M. E. and Farid, A. 2008. Genetic evaluation for some litter and lactation traits in New Zealand White and Baladi Black rabbits. Egyption Poultry Science, 28: 1203-1216.

Ziadi, C., Mocé, M. L., Laborda, P., Blasco, A. and Santacreu, M. A. 2013. Genetic selection for ovulation rate and litter size in rabbits: Estimation of genetic parameters and direct and correlated responses, Journal of Animal Science, 7: 3113-3120. 


$$
\begin{aligned}
& \text { الملخص العربي } \\
& \text { الإستجابة المرتبطه لصفات الخلفة ومحصول اللبن في أرانب النيوزيلندي الأبيض التبائ }
\end{aligned}
$$

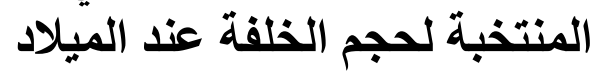

$$
\begin{aligned}
& \text { محمود مصطفي الاطروني1 - وليد شعبان حبثي² } \\
& 1 \text { قسم الإنتاج الحيواني - كلية الزراعة - جامعة بنها - مصر } \\
& 2 \text { قسم الإتتاج الحيواني والداجني - كلية الزراعة - جامعة دمنهور - مصر }
\end{aligned}
$$

هدفت هذه الدر اسة إلي تقييم أثر الإنتخاب لحجم الخلفة عند الميلاد علي صفات الخلفة ومحصـول اللبن في

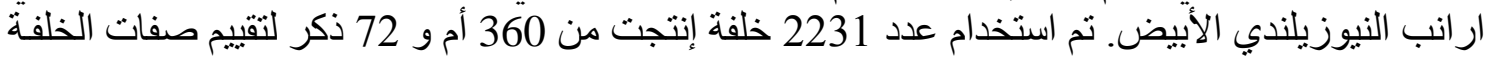

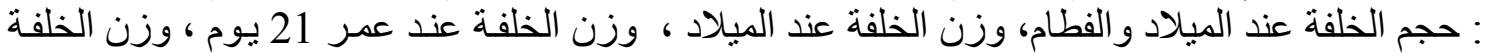

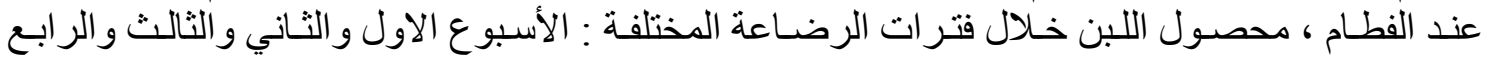

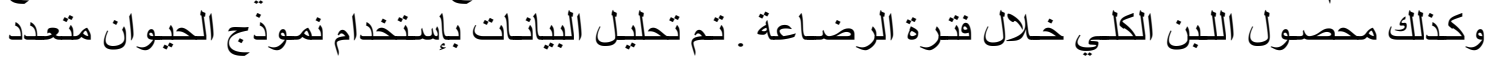

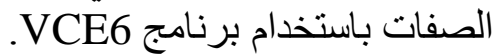

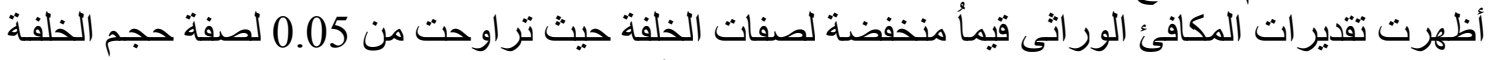

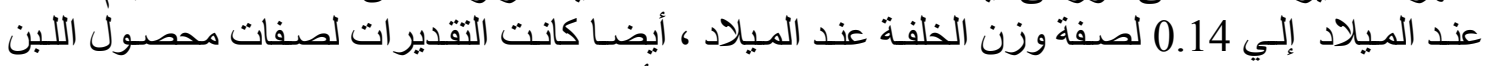

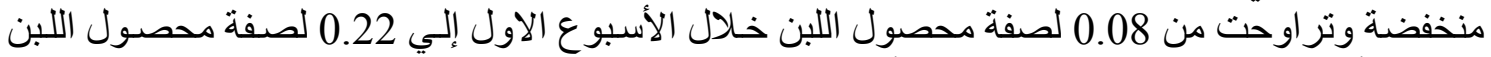

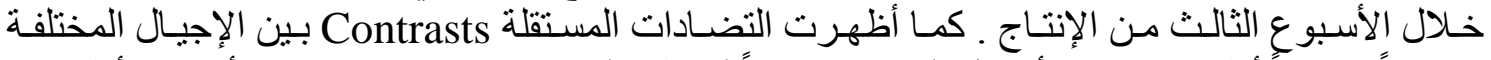

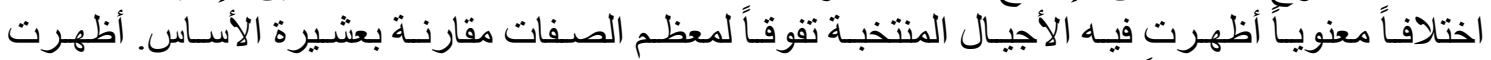

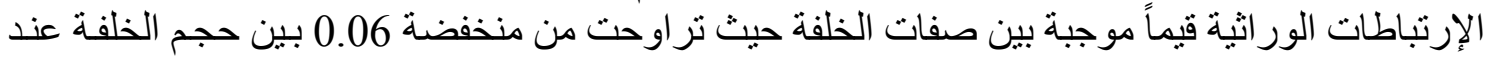

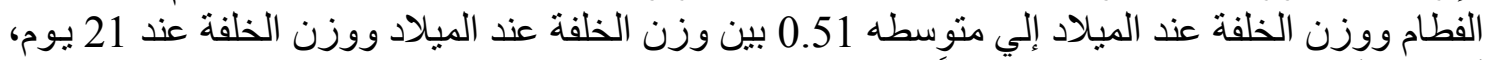

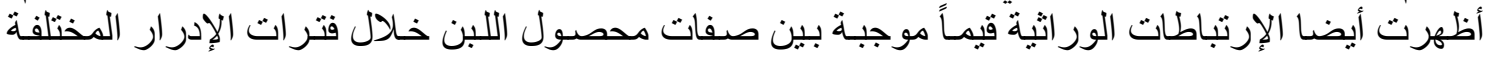

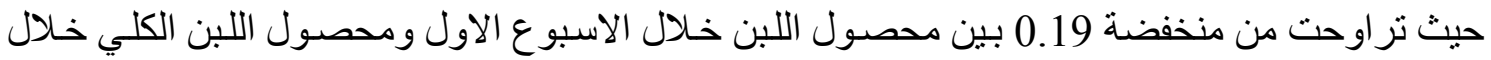
فترة الرضاعة إلي مرتفعة 0.84 بين صفات محصد 0.

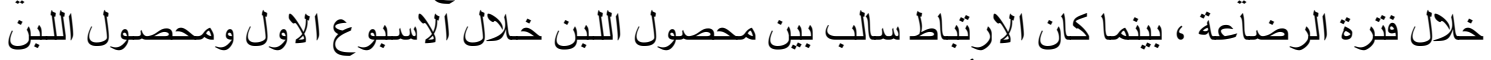

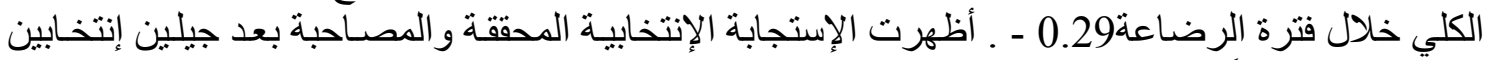

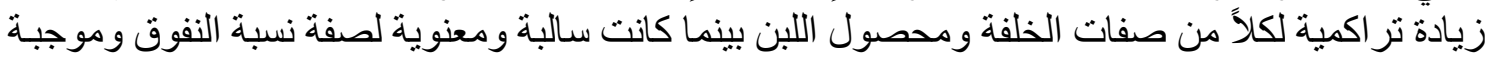
و غير معنوية لصفة نسبة تحويل الحليب. الخلاصة : يمكن التوصية بأن إنتخاب إناث ار انب النيوزيلاندي الأبيض لحجم الخلفة عند الميلاد بمكن أن يحسن صفات الخلفة ومحصول التوصن بان اللبن. 